Article

\title{
Does the Balance Exist between Cost Efficiency of Different Energy Efficiency Measures? DH Systems Case
}

\author{
Ieva Pakere *, Dace Lauka and Dagnija Blumberga \\ Institute of Energy Systems and Environment, Riga Technical University, LV-1048 Riga, Latvia; \\ dace.lauka@rtu.lv (D.L.); dagnija.blumberga@rtu.lv (D.B.) \\ * Correspondence: ieva.pakere@rtu.lv
}

Received: 27 August 2020; Accepted: 30 September 2020; Published: 2 October 2020

check for updates

\begin{abstract}
The main aim of this study is to evaluate the results achieved by implementation of different support policies in form of subsidies for energy efficiency improvements and transition to renewable energy sources. The article compares the energy efficiency measures in district heating systems with other support program. In order to assess the effectiveness of implementation of different renewable energy technologies and energy efficiency projects, the levelized costs of saved energy for different support programs were determined. Authors compared different co-financed projects related to replacement of fossil fuel energy sources in district heating (mainly to biomass) and the installation of new biomass boilers, heat pumps, solar collectors and other local technologies in municipal buildings. Results show that financial support for energy efficiency measures in industrial enterprises and district heating systems has been most cost-effective, mainly due to the low co-financing rate (30\%) and the high potential for energy savings in different production processes. Authors have identified the blind-spots within the funding allocation for different municipalities, which is not always dedicated to achieved energy savings.
\end{abstract}

Keywords: energy efficiency measures; efficient district heating system; cost of saved energy; renewable energy policies

\section{Introduction}

The necessity to increase the energy efficiency and the use of carbon neutral energy sources has been the highlight of political debates for decades. The development of energy efficient and climate neutral energy sector is related to many different energy efficiency measures in both energy supply, energy transmission and energy consumer side. In order to prioritise possible energy efficiency measures, one can evaluate the technical and economical results, the social and environmental impact and different other aspects [1]. Even more, the implemented energy efficiency measures in different energy system elements can have a complex nature, for example, the renovation of buildings and reduction of energy consumption causes a necessity to also change the operation conditions of district heating system [2].

The direct benefits from energy efficiency improvements or use of renewable energy sources (RES) is not always in balance with the necessary investments [3]. By taking into account the overall social, economic and environmental gains, the international and national support policies are introduced for different measures related to moving toward carbon neutrality. In addition, the polluter pays principle is applied by introducing different tax policies on fossil fuel use and emission of other environmental pollution.

Subsidies and taxation are common part of overall energy and climate policies of European countries. Bian and Zhao [4] have compared the different effects of those two policy measures in 
manufacturing and retail industries. The authors are taking into account the overall social welfare and environmental performance. In case of the subsidy policy, more resources are necessary for reducing emissions, but it does not always result in lower net emissions. However, subsidies work well when applied to market-ready technologies that are prepared to move from prototype to mass production. Subsidies aim to reduce technology costs, demonstrate technological feasibility, identify potential market barriers and increase market penetration [5]. These instruments can be converted into loans or investments if the renewable energy technology is commercially successful. [6]

There is wide variety of the possible support measures for increasing renewable energy share including feed in tariffs, renewable portfolio standards, production tax credits, capacity or production-based subsidies or even benchmarks, etc. [7]. When evaluating how efficient those policies are, different indicators can be used-the total investments, specific renewable energy costs, achieved share of renewable energy, the amount of subsidies, consumer prices and others rates [8]. The analysis shows that for short run, the subsidies which are applied for certain energy output are more cost-effective, but for the long-term perspective, the policies related to installed capacity might be more effective due to reduced technology costs [9].

Abrell et al. [10] have estimated the costs for reducing $\mathrm{CO}_{2}$ emissions through subsidies in Germany and Spain. The authors have obtained that the costs for solar technologies are much higher (411 to $1944 \mathrm{EUR} / \mathrm{t} \mathrm{CO}_{2}$ ) than for the wind technologies (82 to $276 \mathrm{EUR} / \mathrm{tCO}_{2}$ ). To determine those costs, authors estimated an electricity supply, the impacts of renewable energy generation on electricity prices, the production of conventional electricity producers, $\mathrm{CO}_{2}$ abatement and costs through RES policies. Similar cost ranges are obtained in the evaluation of the Italian support schemes- $165 \mathrm{EUR} / \mathrm{tCO} \mathrm{C}_{2}$ for wind turbines and around $1000 \mathrm{EUR} / \mathrm{t} \mathrm{CO}_{2}$ for solar technologies [11].

Additional action for transition to the carbon neutral energy sector is a reduction of primary energy consumption trough different energy efficiency measures. One of popular measures in different countries is grant for building renovation in order to reduce the energy consumption for heating [12,13]. By renovating buildings, it is possible to reduce up to $50 \%$ of buildings' heat consumption for space heating but it requires high amount of investments. For the evaluation of energy efficiency support measures in building sector, Blumberga et al. [14] have used the system dynamics approach to compare the scenarios with different amounts of subsidies and support intensities for building renovation. Results showed that even with a high support intensity for building refurbishment additional energy efficiency measures will be necessary to reach the overall national energy efficiency and carbon neutrality goals. Those could include the energy efficiency improvements in energy production and transition by moving toward 4th generation district heating system [15]. Large share of heat in buildings is provided by district heating systems that use fossil fuel resources. Therefore, the reduction of heat consumption in buildings increase the share of renewable energy in gross final energy consumption and reduce the country's total green-house gas (GHG) emissions [16,17]. It is also important to promote the use of local RES in district heating by reconstructing existing and constructing new systems, as well as to promote the energy efficiency of industrial buildings. [18]

Cho et.al [19] have evaluated the cost effectiveness of several energy efficiency programs in Switzerland and 11 states in the United States of America (US) by determining the levelized costs of saved energy (LCSE) from the perspective of program administrators. The determined values for LCSE in US ranged greatly both for residential and commercial/industrial sectors. The average value for residential sector reached $0.33 \mathrm{USD} / \mathrm{kWh}$, but for industrial-0.22 USD $/ \mathrm{kWh}$ in 2015 . The higher cost effectiveness is reached in commercial/industrial sector because enterprises are reluctant to invest in projects that are not financially viable.

When evaluating the energy efficiency measures and integration of RES in DH one of possible evaluation criterion is the levelized costs of heat which indicates the long run production costs by taking into account total investment and operation costs, subsidies and produced amount of energy as well as other parameters. Moller et.al. [20] have evaluated the existing policy instruments in DH 
sector in Baltic States by focusing on flexibility component, which mainly have not been the priority for energy efficiency measures.

The comparison of the cost effectiveness for different energy and climate policies implemented in both district heating system and other energy sector elements have not yet been evaluated in detailed perspective. Therefore, the main aim of the particular study is to evaluate the results achieved by implementation of different support policies for energy efficiency measures and installation of RES technologies in form of subsidies. Authors compare the support programs for building renovation, district heating systems and industrial processes to reduce the overall energy consumption and improve the energy efficiency. The bottom up approach has been used by determining the efficiency indicators for particular projects and evaluation trough regression analyses. It allowed identifying the blind spots within the monitoring of financial support allocation.

\section{Materials and Methods}

The article analyses two different types of climate policy measures-the subsidies for RES technologies in order to increase the RES share in gross domestic consumption and the grants for the energy efficiency measures in order to decrease the gross energy consumption. In total, the results from six different funding programs for energy efficiency improvements and two different grant programs for installation of RES have been compared. Further, the main financial sources have been described for the analysed programs.

\subsection{The Overview on Analysed Funding Programs}

One of the analysed financial sources is the Climate Change Financial Instrument (CCFI)-the Latvian state budget program launched from 2012 to 2015. The financing of the program was formed by the Proceeds from the Assigned Amount Units Purchase Agreements, which are made within the international emissions trading under the Kyoto Protocol. The AAU sales were possible, because in the Kyoto Protocol for period of 2008-2012 Latvia did not need all available AAU, and the potential excess was at least 40 million units. [21].

In total, the CCFI offered 16 different project applications on different topics, with some project applications having several rounds. Each project call had its own specific goal, for example to develop technologies to reduce GHG, increase energy efficiency in higher education buildings, promote technology transition from fossil to renewable energy, etc. Funding for CCFI competitions had five main areas-reducing GHG emissions from transport, improving energy efficiency in public and private sectors (buildings), power-saving solutions in the public and private sector, integrated solutions for reducing GHG emissions in technological processes, development of renewable energy technologies. [21]

The Cohesion Fund (CF) is one of the financial instruments of the European Union's (EU) regional policy aimed at bridging economic and social disparities between countries. The Fund contributes financially to projects aimed at achieving EU environmental and transport objectives, EU policies and directives. Latvia have one operational program "Growth and employment" for the 2014-2020 programming period which included the support for the energy efficiency and RES projects. In total, the program identified nine lines of action, each with a fixed share of funding including research, technological development and innovation, transition to a low-carbon economy in all sectors, environmental protection and resource efficiency, sustainable transport system, etc. During the programming period, projects in Latvia are administered by the Central Finance and Contracts Agency (CFCA) which is direct management institution subordinated to the Ministry of Finance. The available support to promote efficient use of energy resources, reduction of energy consumption and transition to RES in the industrial sector have been EUR 24 million since December 2016. In total, 57 million EUR have been dedicated for energy efficiency projects and transition to RES in district heating. 
The European Regional Development Fund (ERDF) was created in 1975 to redress regional disparities within the Community. The following measures is eligible for ERDF funding: improving the business environment and increasing competitiveness, particularly in small and medium-sized enterprises, local economies, including conservation of tourism and cultural heritage, research and technological development, the development of local, regional transport, telecommunications and energy networks and the infrastructure supporting them, etc. In addition, ERDF funding is being provided for public and private energy efficiency improvements alongside to public and private investments [22]. For the planning period 2014-2020 the implementation of support policy for energy efficiency measures in apartment buildings was coordinated through state-owned development finance institution ALTUM which offers state aid for various target groups with the help of financial tools (such as loans, credit guarantees, investing in venture capital funds, etc.). The energy efficiency projects in public and municipal buildings are administered by the CFCA. The most of financial support from ERDF fund in the particular planning period have been dedicated for energy efficiency measures in apartment buildings reaching EUR 130 million. The total co-financing for state owned public buildings was EUR 95 million, but for municipal building renovation-EUR 46 million. Within the study, authors also analyse the results of apartment building energy efficiency projects implemented in the previous financing period from 2009 to 2013. It was coordinated by Investment and Development Agency of Latvia (LIAA), subordinated to the Ministry for Economics of Latvia. The total funding reached around EUR 95 million for the energy efficiency measures in apartment buildings within the previous planning period.

\subsection{Methodology Steps for Determination of Cost Effectiveness}

The authors use bottom up approach by evaluating particular projects realised within the different funding programs. Figure 1 shows the overall steps of the study in order to compare the efficiency of different support programs and to identify the blind spots-weak points of each program that need to be improved. The first step of the study is the overall investigation of all available national support measures for different stakeholders related to energy efficiency and RES.

In order to quantify the results of each support program the authors identified the main indicators, which are used for the comparison. In the particular study, authors use two main indicators for the evaluation of energy efficiency programs - the levelized costs of saved energy (LCSE) and specific costs of avoided $\mathrm{CO}_{2}$ emissions. According to previous studies, the LCSE can be determined as a total project's costs divided by the total energy savings and taking into account the capital recovery factor $(1,2)[19]$.

$$
\begin{aligned}
\text { LCSE }= & \frac{\text { Total investments } \cdot \text { Capital recovery factor }}{\text { Anual energy savings }} \\
& \text { Capital recovery factor }=r \cdot(1+r)^{d}
\end{aligned}
$$

where $\mathrm{r}$ - discount rate; $\mathrm{d}$-average life of the energy efficiency measure

Capital recovery factor allows spreading the investments over the project lifetime by applying the discount rate and the lifetime of energy efficiency measure. The LCSE describes the energy saving costs from the funding provider perspective and include all technology and project administration costs, but does not indicates the overall program administration costs (including administration, marketing, training or project evaluation). Within the determination of the LCSE, authors use the discount rate $5 \%$ for all programs which is in line with other research. The used lifetime differ for each energy efficiency measures according to their estimated operation. Authors use lifetime of 25 years for building refurbishment projects, and 20 years for industrial and district heating energy efficiency measures. 


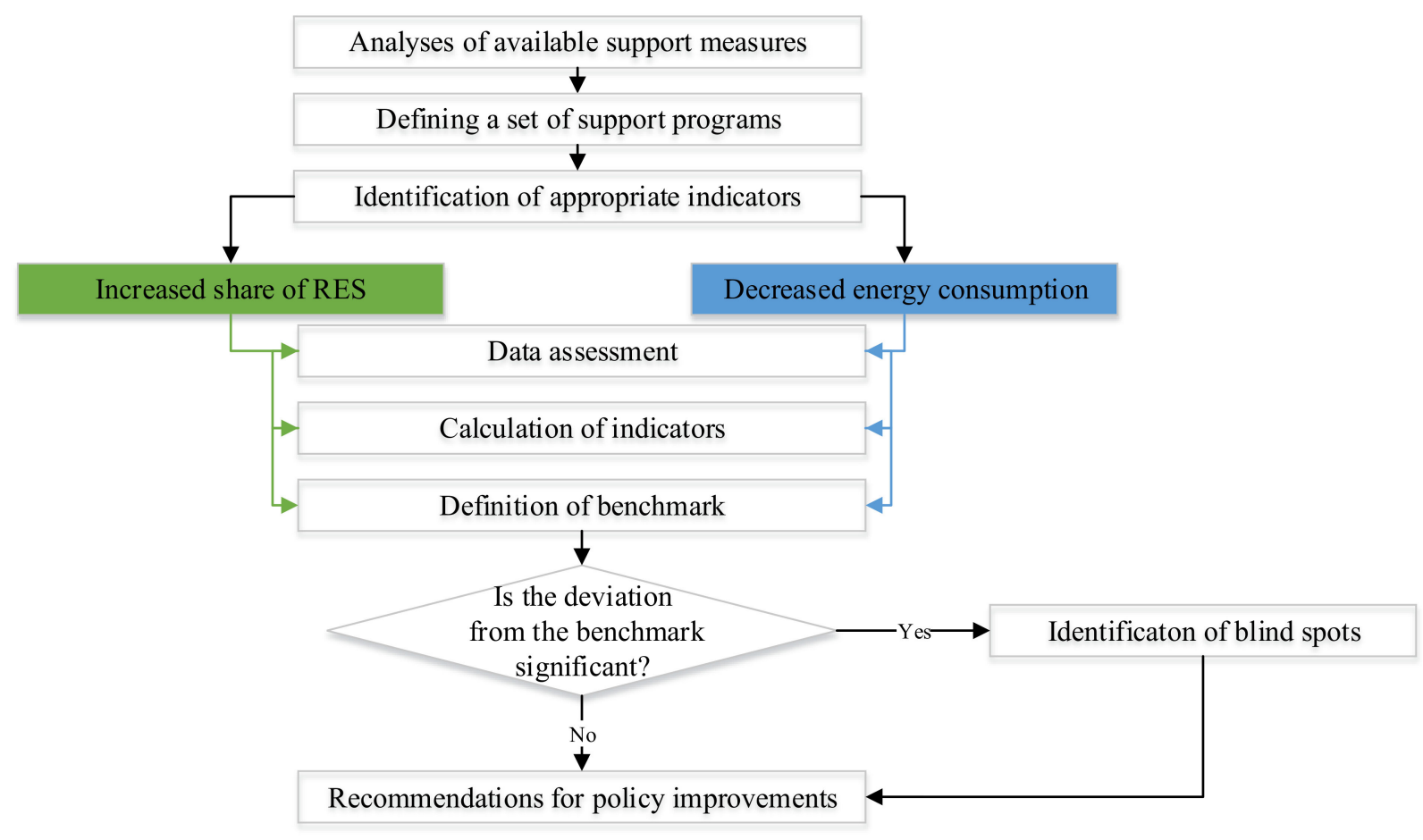

Figure 1. Main steps of the research.

As the energy efficiency measures brings the overall environmental benefits, authors include the specific costs of avoided $\mathrm{CO}_{2}$ emissions within the evaluation of program cost effectiveness. It is determined by dividing the total co-financing by estimated avoided $\mathrm{CO}_{2}$ emissions per year (3).

$$
\text { Specific cost of avoided } \mathrm{CO}_{2}=\frac{\text { Total investments }}{\text { Avoided } \mathrm{CO}_{2} \text { emissions }}
$$

The avoided $\mathrm{CO}_{2}$ emissions have been identified in all projects realised within the CCFI program because the main target of the program was to decrease the national GHG emissions. However, the projects co-financed from other funds were not always obligated to achieve certain $\mathrm{CO}_{2}$ reduction. Therefore, authors have estimated the amount of avoided $\mathrm{CO}_{2}$ emissions trough energy savings by applying particular $\mathrm{CO}_{2}$ factors.

In order to assess the effectiveness of the implementation of RES policies, the simplest indicators measure the installed capacity or energy produced and its increase in absolute units or percentages. Determining the energy produced has advantages over estimating capacity gains, as it does not measure the productivity of renewable energy installations, for example through efficient deployment, maintenance and integration. Cost effectiveness is defined as the ratio of the result achieved to the investment, measured at a given point in time (static efficiency). Dynamic efficiency increases the time dimension of the future by incorporating the amount of innovation to improve the output-investment ratio. However, it is not determined within the particular research. Static efficiency is measured simply by using EUR/MW or EUR/MWh. As discussed in the context of efficiency, the determination of the energy produced is usually more informative than the installed capacity, because it takes into account the efficiency of use.

Further, the required data of realised projects is collected through the in-depth data assessment for the calculation of the indicators. The data have been gathered both from the reports of administrators and determined manually by the information indicated within the project applications. Therefore, the forecasted energy savings and produced amount of energy could be diverse from the actual energy savings. 
The regression analyses have been carried out to justify the achieved energy savings with the provided financial support. For each of the analysed programs the benchmark value is defined as an average value of indicator value of all projects. If there is a significant deviation of project results from the defined benchmark than it is necessary to identify the main reasons and blind spots for such deviation. Further, the overall conclusions and recommendations can be driven regarding the implementation of particular policy measures.

\subsection{Evaluation of Renewable Energy Integration Projects}

Comparison of the analysed RES support programs for district heating and individual heating solutions financed from two funds is presented in Table 1. Although a number of policies have been implemented, there is currently a lack of information regarding the achieved performance of realised projects for most of programs. From the publicly available information and descriptions of the implemented projects, the specific costs for the two implemented programs were calculated and summarized.

Table 1. Overview on RES policy analyses.

\begin{tabular}{ccc}
\hline Name of Program & $\begin{array}{c}\text { "Promote Energy Efficiency } \\
\text { and Use of Local RES in } \\
\text { District Heating” }\end{array}$ & $\begin{array}{c}\text { "Technology Transition from } \\
\text { Fossil to Renewable Energy" } \\
\text { and “Complex Solutions for } \\
\text { Reducing Greenhouse Gas } \\
\text { Emissions" }\end{array}$ \\
\hline Funding & CF & CCFI \\
\hline Applicants for support & District heating suppliers & Municipalities \\
\hline Implementation period & $2018-2020$ & $2010-2012$ \\
\hline Number of analysed projects & 18 & 39 \\
\hline $\begin{array}{c}\text { Maximal support intensity, } \% \\
\text { Installed RES capacity, MW }\end{array}$ & $30 \%$ & $75 \%$ \\
\hline $\begin{array}{c}\text { Specific costs of RES installation, } \\
\text { EUR/kW }\end{array}$ & 136 & 262 \\
\hline $\begin{array}{c}\text { Specific cost of energy produced, } \\
\text { EUR/ MWh }\end{array}$ & No information & 7.3 \\
\hline $\begin{array}{c}\text { Specific GHG emission } \\
\text { reduction costs, }\end{array}$ & No information & 443 \\
\hline
\end{tabular}

In the CF program, "Promote energy efficiency and use of local RES in district heating", 18 projects were identified to replace fossil energy sources (mainly natural gas) with RES (mostly biomass). The total installed capacity of these projects reaches $136 \mathrm{MW}$. The total investments for particular projects amount to EUR 71 million, of which almost EUR 20 million was granted as EU co-financing. Consequently, the specific costs of the co-financing granted per MW of installed RES capacity amount to EUR 143 thousand. From the available information, it was not possible to determine the estimated amount of energy produced or the amount of GHG emissions avoided in these projects.

In the period 2010-2012, various project applications were conducted to obtain funding from the CCFI. Authors have evaluated the projects implemented by municipalities within the programs "Integrated solutions for reducing greenhouse gas emissions" and "Technology transition from fossil to renewable energy" in which new boilers, heat pumps, solar collectors and other local technologies were installed within the municipal buildings (schools, kindergartens, administration buildings, social centres, sport halls, etc.). The total RES capacity in the analysed projects reached $26 \mathrm{MW}$. The total funding of these projects was almost 7 million with the CCFI co-financing of EUR 5.2 million. Specific cost per installed RES capacity is EUR 202 thousand, which is higher than in the district heating project program described before. Several aspects can explain this: the installations in district heating systems 
are with larger capacity therefore with lower specific costs and there was higher share of the more expensive and innovative RES technologies (solar collectors, heat pumps) in the CCFI program.

\subsection{Energy Efficiency Project Evaluation}

Various support programs promoting energy efficiency have been implemented in Latvia. However, there is lack of detailed review regarding the obtained results to identify the main benefits and bottlenecks of implemented projects. Therefore, authors have evaluated several energy efficiency programs to compare the obtain energy savings and provided co-financing. An overview of the analysed energy efficiency programs financed by different funds is presented in Table 2, along with the information regarding the supported applicants, implementation period, support intensity and number of projects included within the analyses.

Table 2. Overview on analysed policy programs related to energy efficiency increase.

\begin{tabular}{|c|c|c|c|c|c|c|c|}
\hline No & Program Aim & $\begin{array}{l}\text { Applicants for } \\
\text { Support }\end{array}$ & $\begin{array}{l}\text { Implementation } \\
\text { Period }\end{array}$ & Fund & Supported Activities & $\begin{array}{c}\text { No of } \\
\text { Analysed } \\
\text { Projects }\end{array}$ & $\begin{array}{l}\text { Support } \\
\text { Intensity }\end{array}$ \\
\hline 1 & $\begin{array}{l}\text { To promote efficient } \\
\text { use of energy } \\
\text { resources, reduction } \\
\text { of energy } \\
\text { consumption and } \\
\text { transition to RES in } \\
\text { the industrial sector }\end{array}$ & $\begin{array}{c}\text { Manufacturing } \\
\text { companies }\end{array}$ & 2018-2020 & $\mathrm{CF}$ & $\begin{array}{l}\text { Building renovation, } \\
\text { replacement of } \\
\text { production } \\
\text { equipment, } \\
\text { reconstruction of } \\
\text { heating system }\end{array}$ & 39 & $30 \%$ \\
\hline 2 & $\begin{array}{c}\text { Promote energy } \\
\text { efficiency and use of } \\
\text { local RES in district } \\
\text { heating }\end{array}$ & $\begin{array}{l}\text { District heating } \\
\text { companies }\end{array}$ & 2018-2020 & $\mathrm{CF}$ & $\begin{array}{l}\text { Modernisation of } \\
\text { heating networks }\end{array}$ & 29 & $30 \%$ \\
\hline 3 & $\begin{array}{c}\text { Measures for } \\
\text { Improvement of } \\
\text { Thermal Insulation of } \\
\text { Apartment buildings }\end{array}$ & $\begin{array}{l}\text { Owners of } \\
\text { apartment } \\
\text { buildings }\end{array}$ & 2009-2013 & ERDF & Building renovation & 487 & $50 \%$ \\
\hline 4 & $\begin{array}{l}\text { Complex solutions for } \\
\text { reducing greenhouse } \\
\text { gas emissions }\end{array}$ & Municipalities & 2010-2012 & CCFI & $\begin{array}{l}\text { Building renovation, } \\
\text { ventilation system } \\
\text { reconstruction, } \\
\text { heating system } \\
\text { reconstruction }\end{array}$ & 85 & $75 \%$ \\
\hline 5 & $\begin{array}{l}\text { Aid for the } \\
\text { implementation of } \\
\text { energy efficiency } \\
\text { improvement } \\
\text { measures in } \\
\text { apartment buildings } \\
\text { by apartment owners }\end{array}$ & $\begin{array}{l}\text { Owners of } \\
\text { apartment } \\
\text { buildings }\end{array}$ & 2018-2020 & $\mathrm{CF}$ & $\begin{array}{l}\text { Building renovation, } \\
\text { ventilation system } \\
\text { reconstruction }\end{array}$ & 48 & $50 \%$ \\
\hline 6 & $\begin{array}{l}\text { To promote energy } \\
\text { efficiency and use of } \\
\text { renewable energy } \\
\text { resources in } \\
\text { municipal buildings }\end{array}$ & Municipalities & 2018-2020 & ERDF & $\begin{array}{l}\text { Building renovation, } \\
\text { ventilation system } \\
\text { reconstruction }\end{array}$ & 68 & $85 \%$ \\
\hline
\end{tabular}

Within the energy efficiency program for industrial companies (Program 1), manufacturing companies were encouraged to implement a wide range of energy efficiency measures, from building renovation to change of production equipment. Another energy efficiency program for district heating suppliers and heat producers provided a financial support for energy efficiency improvements in DH systems (Program 2). It was mainly used for heat pipeline reconstruction projects. There were two different programs dedicated for renovation of apartment buildings (Programs 3 and 5). The measures included both the insulation of external constructions and the reconstruction of ventilation and heating systems. Similar activities were supported in the municipal buildings within two programs (Programs 4 and 6).

In the project call of Program 2 for district heating companies, the criterion for the minimal achievable heat savings per project co-financing in case of pipe reconstruction was $1.5 \mathrm{kWh} / \mathrm{EUR}$. 
The average savings per financing reached was $4.2 \mathrm{kWh} / \mathrm{EUR}$ with maximal value of $8.9 \mathrm{kWh} / \mathrm{EUR}$. For Program 1, the project administrators have determined the eligible costs of the project in relation to the planned heat energy or power savings over the life cycle of the investment. The value required to be lower than the $0.06 \mathrm{EUR} / \mathrm{kWh}$. However, all the project applicants planned the higher cost effectiveness and the average value was $0.02 \mathrm{EUR} / \mathrm{kWh}$. The additional criterions within the project evaluation were the ratio of energy savings that should be at least $15 \%$ of energy consumption before the energy measures. The reduction of GHG emissions were not mandatory in this call for proposals.

The cost effectiveness criterions were made easier in case of energy efficiency measures in the apartment buildings. In Program 5, the main achievable cost effectiveness indicator was simple payback time, which should be shorter than 20 years. In Program 3, the renovation was supported if it results in at least $20 \%$ heating energy savings.

The project results in Program 4 were mainly evaluated trough achieved reduction of GHG emissions, which should be at least $0.42 \mathrm{~kg} \mathrm{CO}_{2} / \mathrm{EUR}$. The average value for the evaluated building renovation projects were $0.438 \mathrm{CO}_{2} / \mathrm{EUR}$. In Program 6, the energy efficiency indicators to be achieved on the provided funding were not determined. The building renovation were planned in accordance with the municipal integrated development programs.

\section{Results}

In order to compare the effectiveness of different RES technology implementation and energy efficiency projects in district heating and individual heating, the LCSE and the specific energy costs per funding were determined. Currently, none of these programs has a detailed assessment regarding the total energy savings compared to the financial support provided. The section presents the regression analyses results and the developed benchmarks, which can be used when justifying the required project costs for external funding or evaluating the obtained results.

\subsection{Support Policies for RES}

Authors have determined the specific cost of co-financing per amount of energy produced for supported RE technologies in individual heating systems. For different projects, these costs range from 1.3 to 55.8 EUR per MWh. The average indicator for this program is EUR 7.3 per produced MWh, when assuming that the systems run for 20 years. The estimated amount of avoided GHG emission within the analysed projects reached 12 thousand tonnes of $\mathrm{CO}_{2}$ per year. The average specific cost of avoided $\mathrm{CO}_{2}$ was EUR 443 per tonne. The obtained results from the particular analyses shows that the costs of avoided $\mathrm{CO}_{2}$ in case of solar thermal systems are around 435 EUR per tonne, which is lower when comparing to indicated values for solar power technologies from previous analyses in Germany, Spain and Italy. This is due to fact that solar collectors cost less and produce more energy compared to solar panels. Additionally, the applied $\mathrm{CO}_{2}$ coefficients are different for thermal and power systems.

Figure 2 shows the comparison of specific investment costs and specific costs of produced energy for different RE technologies. The combined renewable energy systems represent different technological solutions when energy is produced by using biomass boilers, solar collectors or solar PV panels and heat pumps. Higher costs per produced amount of energy are determined for solar technologies reaching $30 \mathrm{EUR} / \mathrm{MWh}$ in average. When determining the projects costs per installed capacity, the highest values are for heat pumps—around $894 \mathrm{EUR} / \mathrm{kW}$. 


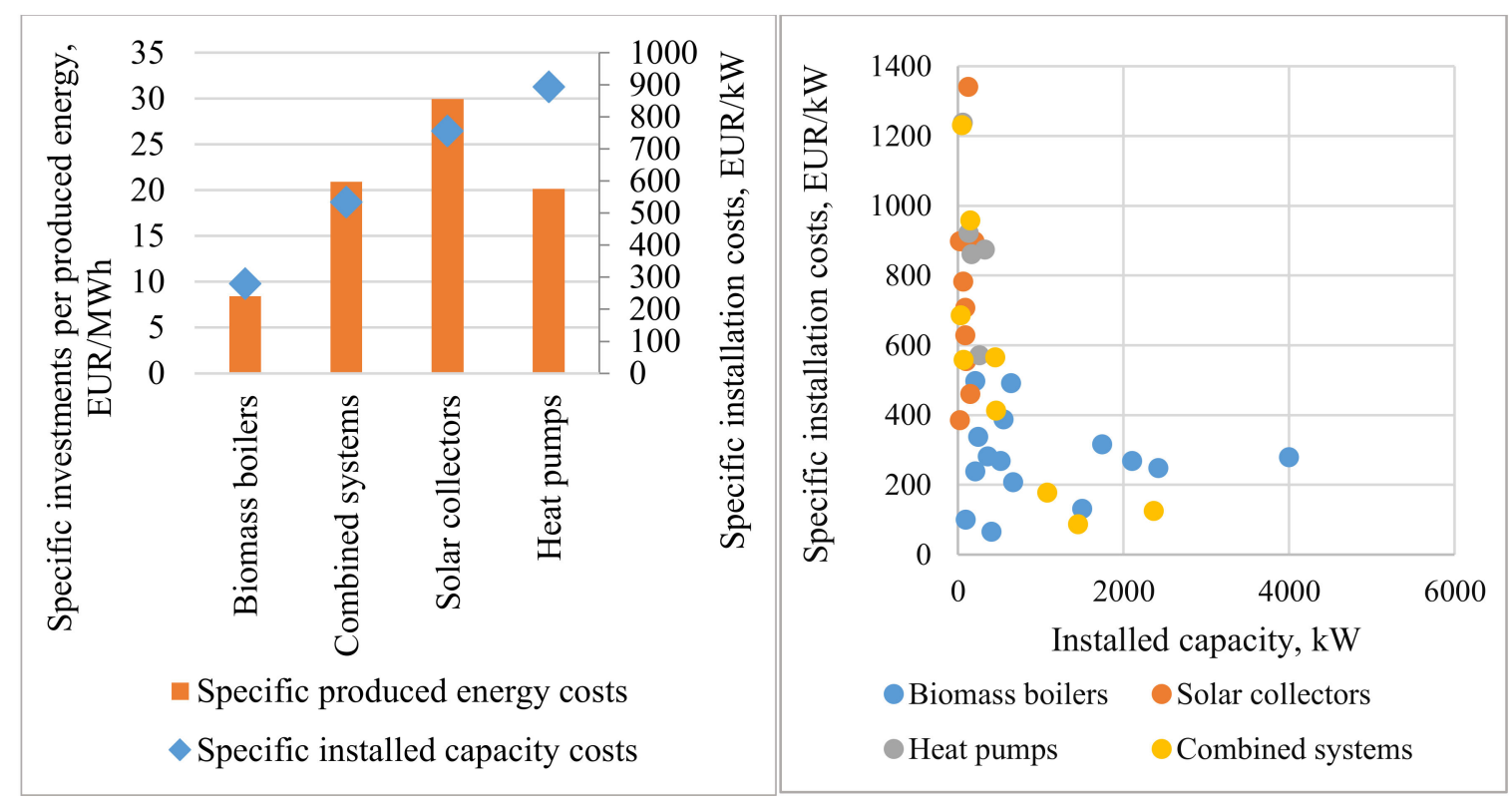

Figure 2. Cost Effectiveness Indicators for different RE technologies in Climate Change Financial Instrument (CCFI) co-financed projects.

For the in-depth evaluation of financing efficiency, the logarithmic and exponential regression analyses were used. Figure 3 shows the results of regression analyses for different projects of RE technologies installed in municipal buildings within the CCF. The specific costs per installed capacity and the installed heat capacity are the main variables evaluated. As can be seen in Figure 3a, the specific costs for biomass boilers differ a lot. In case of small-scale systems (around $200 \mathrm{~kW}$ ), the specific costs can differ even five times from $100 \mathrm{EUR} / \mathrm{kw}$ to almost $500 \mathrm{EUR} / \mathrm{kW}$. The main reasons for such variance are the use of diverse biomass technologies (wood chip boilers or wood pellet boilers) and the additional measures included in the project such as renovation of existing heating system. Such measures are not always identified within the project description.

The Figure 3 also shows the specific cost limits determined within the project call. These limits differ for biomass boilers depending on the installed capacity. However, the results shows, that in two projects the estimated specific installation costs of biomass boilers (see Figure 3a) are higher than the introduced limits which could be due other energy efficiency measures included in the project application, but not described within the publicly available information. For the heat pump technologies, the cost limitations varied for different HP technologies (water/water, (W10/W35), flued/water (B0/W35), air/water (A2/W35), etc.). Figure 3b shows the bottom and upper limits of specific HP costs allowed within the project applications, which did not depend on the installed capacity of the HP. Similarly, for the solar technologies, the project administrator has determined the allowed specific cost limits for vacuum solar collectors and flat plate solar collectors (see Figure 3c).

From the performed regression analyses authors have determined the potential benchmarks which could be used when evaluating the estimated RE technology costs of particular individual heating project. The benchmark curves in Figure 4 shows that for small-scale projects the specific costs differ a lot for solar collectors, heat pumps, biomass boilers and combined systems. However, the specific investment costs for larger scale projects are more similar for all technologies. The presented benchmarks can be used within the RES project evaluation as the indicative cost curves. 


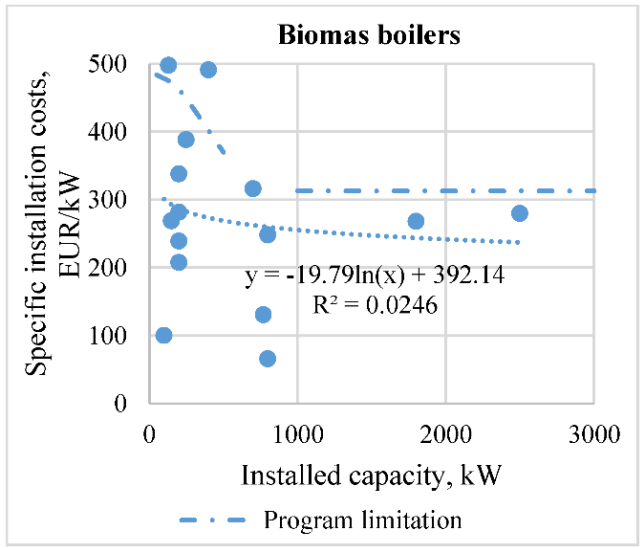

(a)

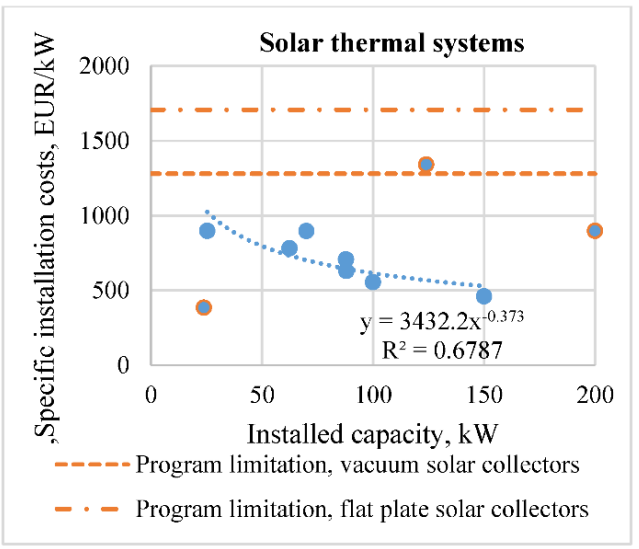

(c)

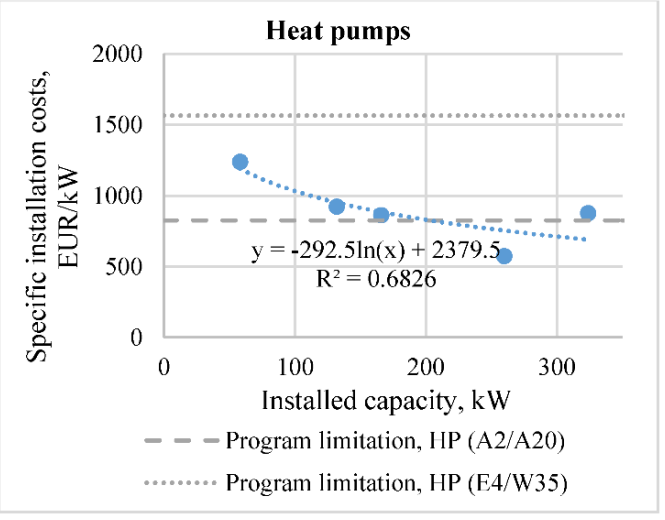

(b)

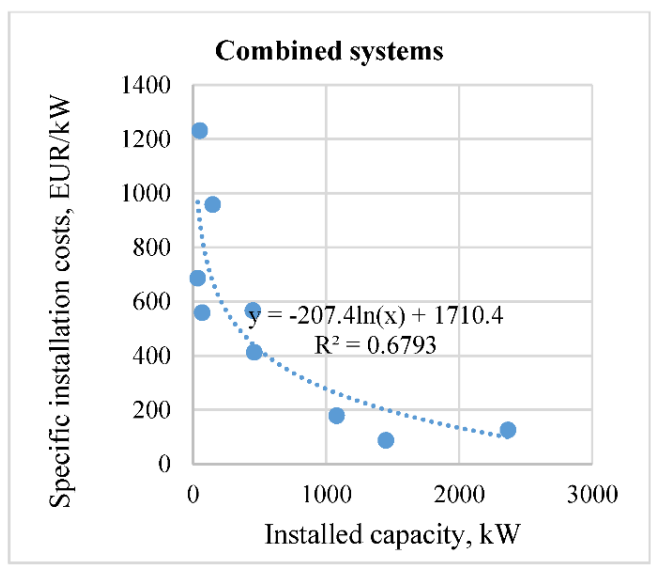

(d)

Figure 3. Regression analyses and the set specific cost limits of the program for different RES technologies: (a) biomass boilers; (b) heat pumps; (c) solar thermal systems and (d) combined systems.
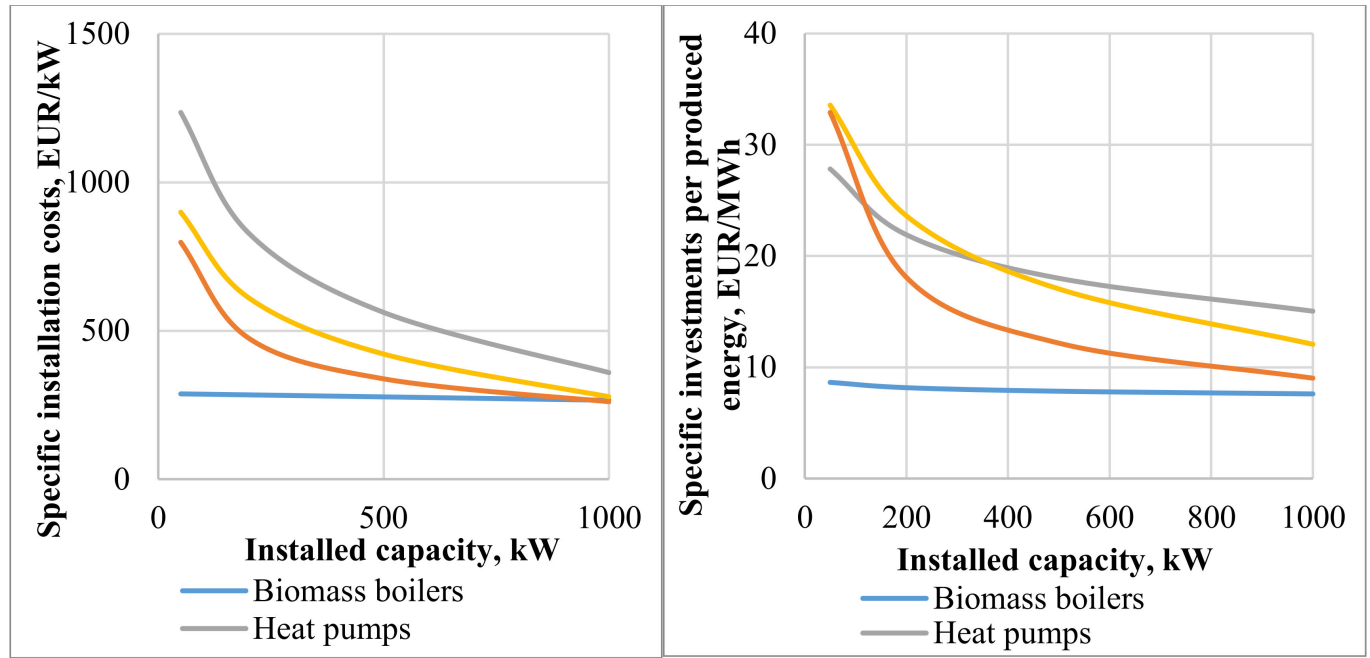

Figure 4. Estimated benchmarks for different RE technologies in individual heating.

\subsection{Evaluation of Energy-Efficiency Programs}

Further section presents the results from investigation of energy efficiency programs. Authors have conducted a detailed data assessment and determined the levelized costs of saved energy for both 
energy efficiency measures in district heating and other sectors. The potential lifetime of measures has been taken into account.

Figure 5 shows the comparison of specific project costs related to obtained energy savings for different energy efficiency program. It can be seen that financial support for energy efficiency improvement in industrial enterprises has been most effective, mainly due to the low co-financing rate $(30 \%)$ and the high potential for energy savings in different production processes. Among the supported sectors, there were wood processing and metalworking companies. Significant differences can be seen in the results obtained in the programs supporting different building renovation projects. Lower specific costs are in projects implemented in Programs 3 and 4 conducted from 2009-2013 when the construction costs were lower. In turn, significantly higher specific costs per saved energy are in the energy efficiency program dedicated to municipal building renovation implemented in 2018-2020.

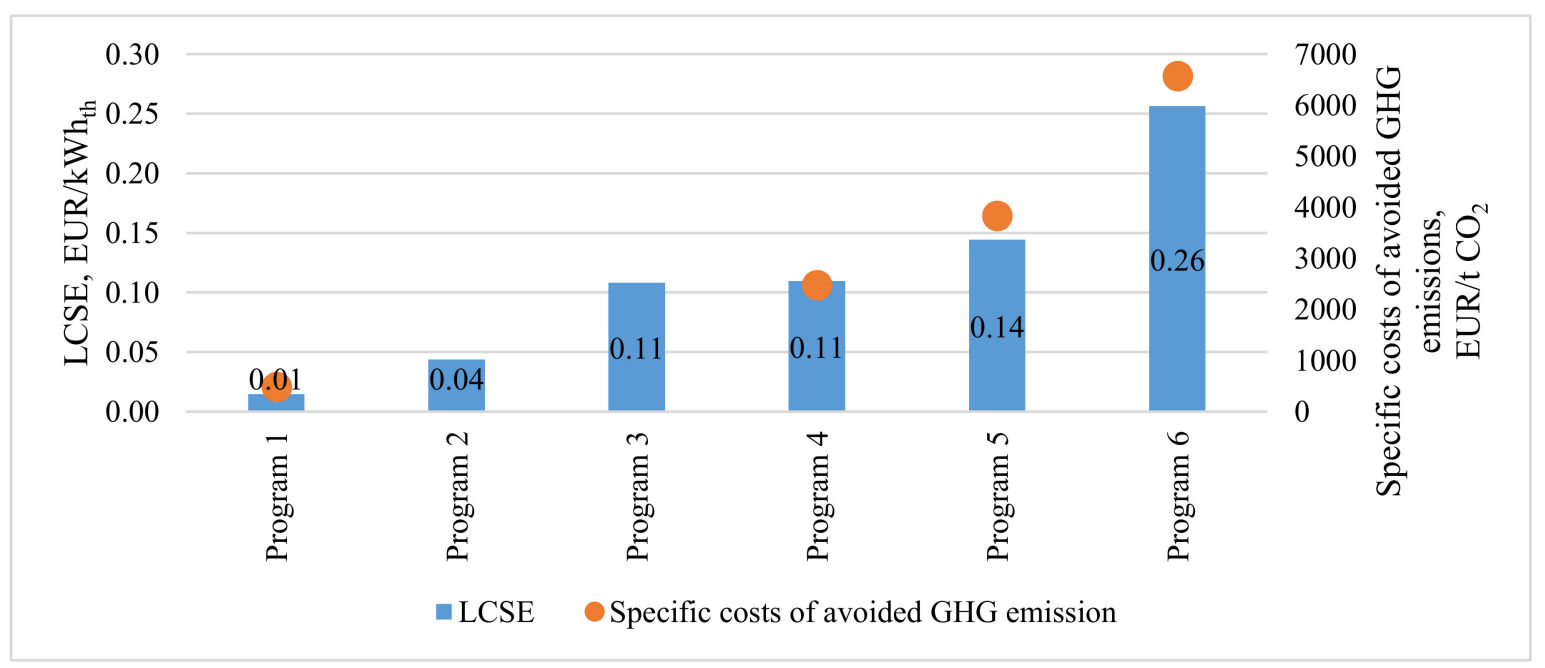

Figure 5. Specific costs for energy savings and specific costs of avoided green-house gas (GHG) emissions of different energy efficiency programs.

When comparing the obtained results with previous studies [19], the determined LCSE for industrial sector $0.028 \mathrm{EUR} / \mathrm{kWh}_{\mathrm{th}}$ (average of Programs 1 and 2) is slightly higher than indicated in the projects realised in Switzerland and US $(0.022 \mathrm{USD} / \mathrm{kWh})$. However, the results of LCSE determined in the other programs for residential and municipal building renovation are much higher than indicated by (Cho et.al, 2019) due to high co-financing share for these energy efficiency measures in Latvia. The average costs per avoided $\mathrm{CO}_{2}$ emissions ranges from $485 \mathrm{EUR} /$ tone $\mathrm{CO}_{2}$ in case of Program 1 to even $6572 \mathrm{EUR} /$ tone $\mathrm{CO}_{2}$ in the case of Program 6.

Figure 6 represents the regression analyses results for analysed energy efficiency programs. As can be seen, the determined regression coefficients are low because there are several factors affecting the energy savings of different energy measures. For example, the achieved energy savings and costs in the case of analysed district heating network, reconstruction projects are highly influenced by the diameters of changed pipes. Several projects included the construction of new heating lines which does not result in direct saving of energy, but brings the overall benefits in case of increased heat density.

The regression analyses for similar projects in case of apartment building retrofitting programs (Programs 3 and 6) and municipality building renovation projects (Programs 4 and 6) shows noticeably different correlation results due to time lag of project implementation. There were also diverse criteria used for project evaluation within those programs. 


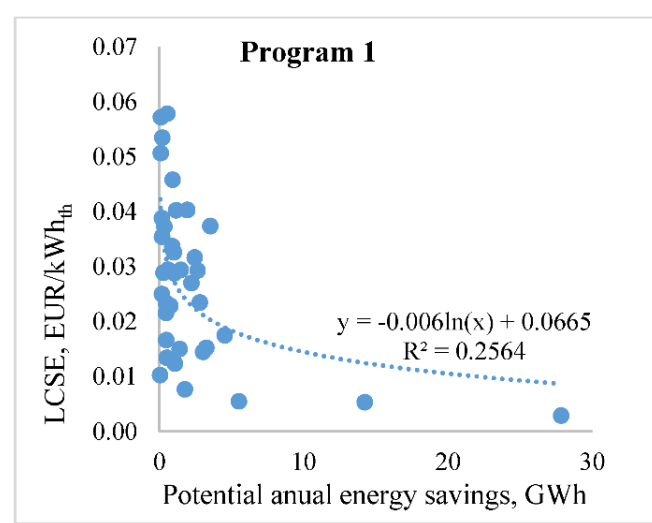

(a)

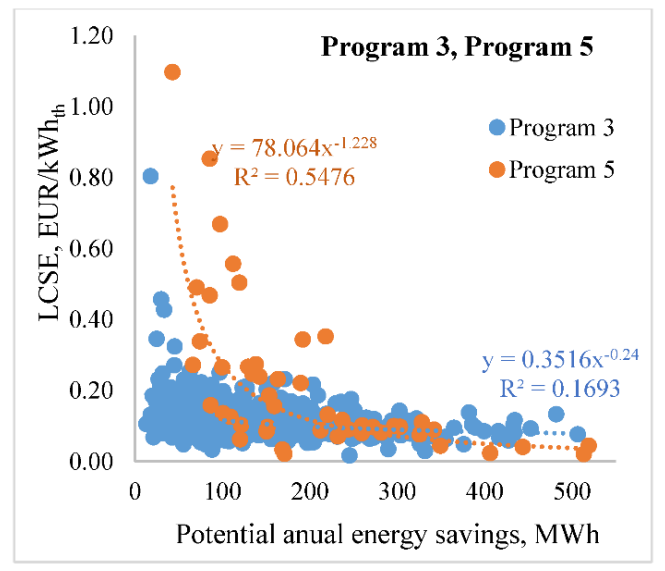

(c)

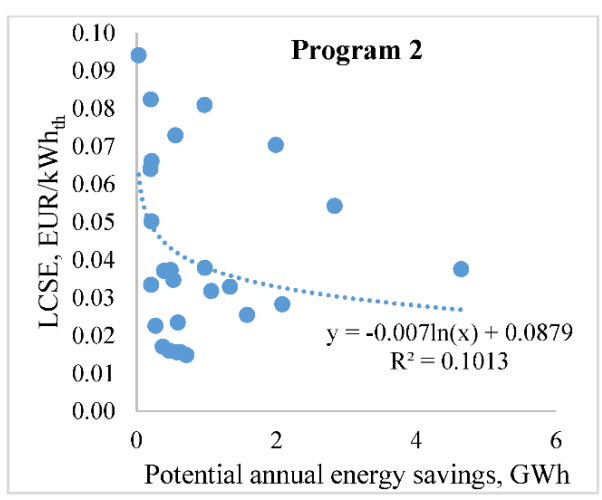

(b)

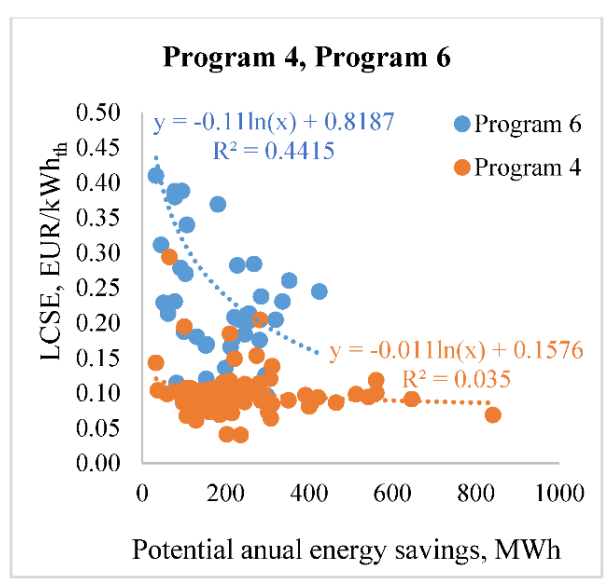

(d)

Figure 6. Regression analyses for analysed energy efficiency programs: (a) Program 1 for manufacturing companies; (b) Program 2 for district heating companies; (c) Program 3 and Program 5 for apartment building renovation; (d) Program 4 and Program 6 for municipalities' building renovation.

The specific costs of energy savings decrease for larger scale projects in which higher energy saving potential can be achieved. The correlation analyses for LCSE and achieved energy saving potential (seen in Figure 7) was determined only in Program 3 for which the necessary data were available. The results of regression analyses have been summarized in Figure 8.

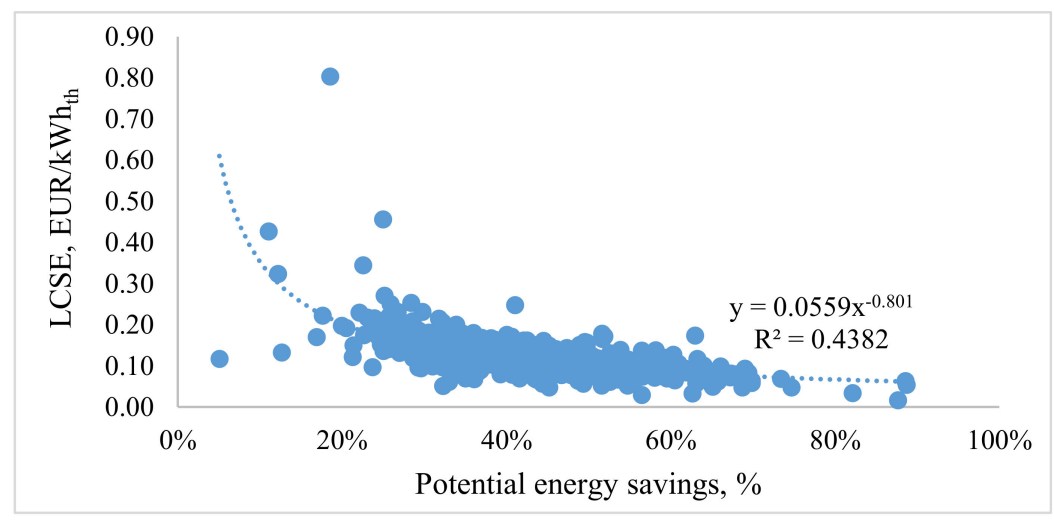

Figure 7. The correlation analyses for levelized costs of saved energy (LCSE) and achieved energy saving potential. 


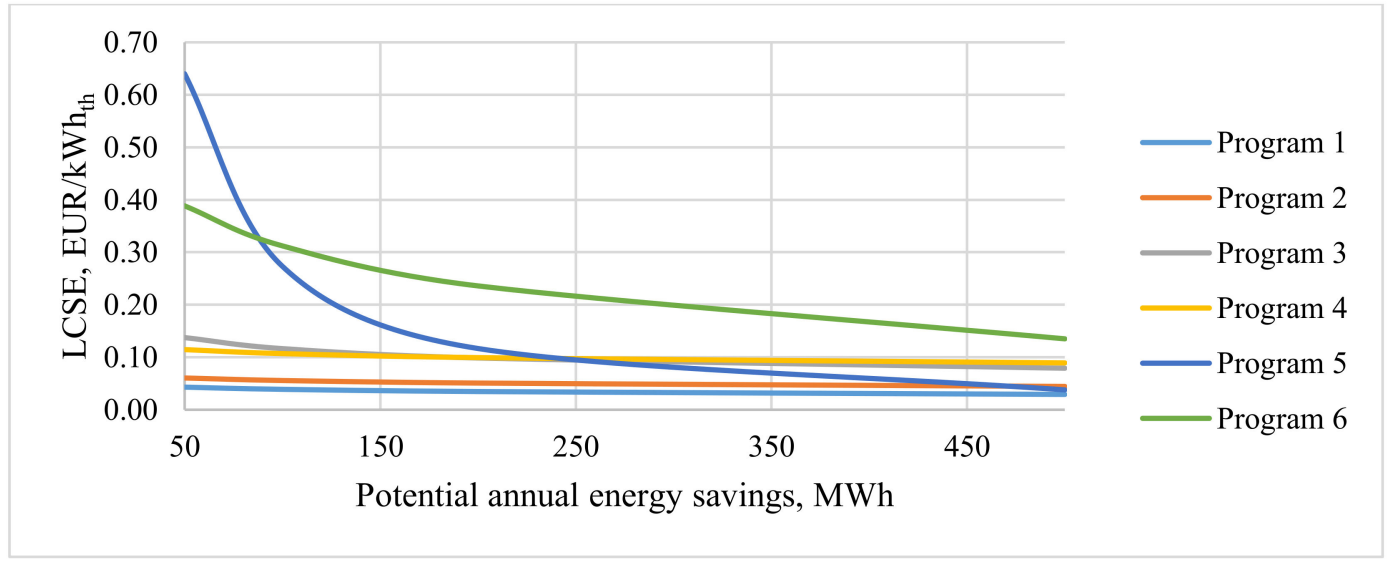

Figure 8. Benchmark of specific costs for energy savings in different programs.

Results shows significant difference between the obtained LCSE values in case of Program 6; therefore, authors have conducted in-depth analyses of specific projects realised in this program. Figure 9 shows the LCSE of the various supported building energy efficiency improvement projects of different municipalities in case of Program 6. It should be noted, that in several projects of other municipalities the estimated energy savings was not even determined and those cannot be further evaluated.

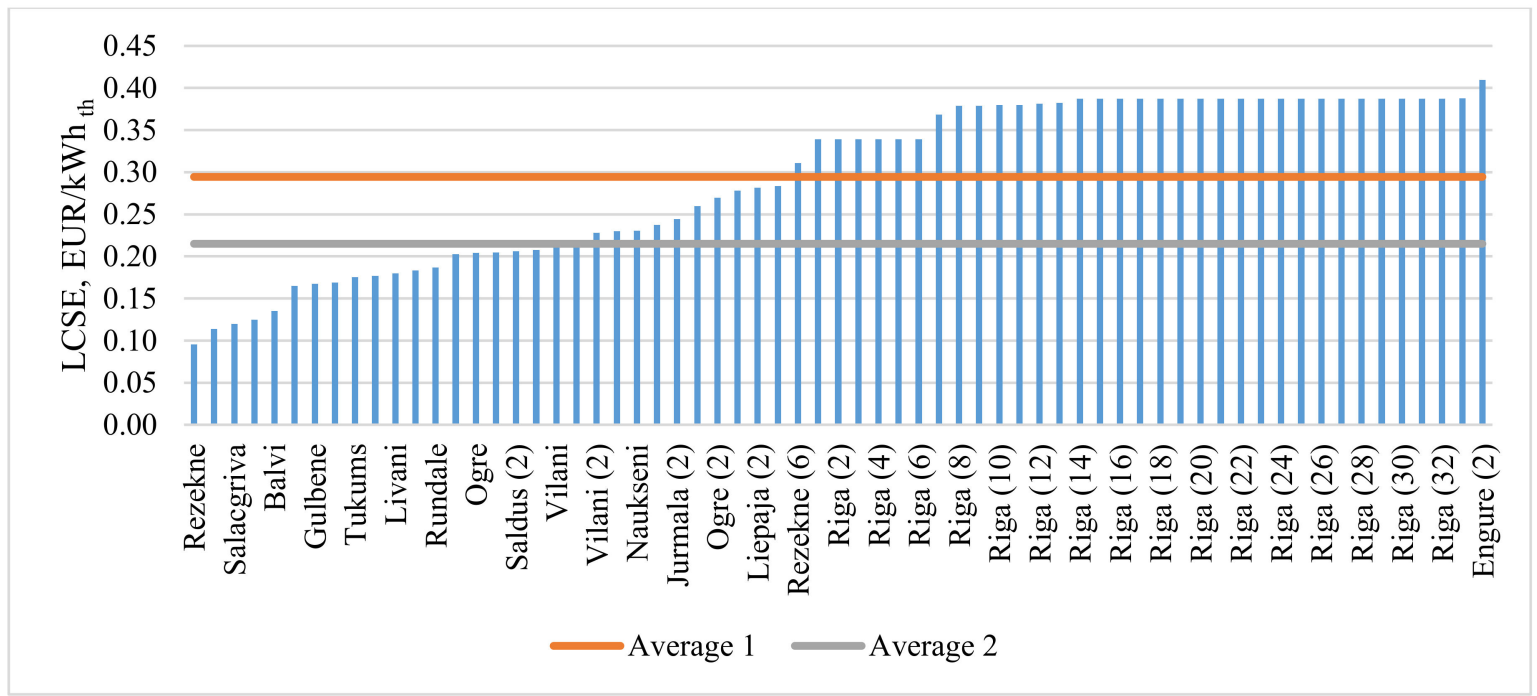

Figure 9. Overview of identified specific costs of energy savings in different Municipalities in case of Program 6.

As can be seen in Figure 9, almost half (31 of 65) of analysed projects in case of Program 6 were realised in capital city Riga. Different kinds of energy efficiency measures were implemented in the school and kindergarten buildings with diverse technical conditions and areas of external constructions. However, the estimated energy savings and requested co-financing is almost the same for all projects, which identifies the blind spots in funding distribution. Therefore, the average specific cost levels differ a lot due to those projects of Riga Municipality. The benchmark line "Average 1" indicates the average LCSE levels of all projects (almost $0.3 \mathrm{EUR} / \mathrm{kWh}$ th), but the "Average 2 " is determined for the projects excluding Riga Municipality and decreases to $0.2 \mathrm{EUR} / \mathrm{kWh}$ th. 


\section{Discussion}

The article analyses the cost efficiency of different energy and climate policy measures in the form of financial support by using bottom up approach. Authors have evaluated two different support programs for installation of RES technologies in local and district heating systems and six different energy efficiency programs for building renovation, district heating network reconstruction and energy consumption reduction in manufacturing. The analysis includes the evaluation of the available information regarding more than 800 different projects realised from 2009 to 2020.

Authors have analysed different co-financed projects related to replacement of fossil fuel energy sources in DH (mainly installation of biomass combustion technologies instead of natural gas boilers) and the installation of new biomass boilers, heat pumps, solar collectors and other local technologies in municipal buildings. The total installed capacity of RES within these projects reached $162 \mathrm{MW}$. The specific costs of the co-financing granted per kW of installed RES capacity amount to 143 EUR in DH projects and EUR 202 in municipalities projects. The installations of DH systems are with larger capacity therefore with lower specific costs. Additionally, there was higher share of the more expensive and innovative RES technologies (solar collectors, heat pumps) in local heating projects. The regression analyses results showed a high deviation of specific installation costs for projects related to biomass boiler installation ranging from 66 to $490 \mathrm{EUR} / \mathrm{kW}$.

To evaluate the cost effectiveness of different energy efficiency programs authors have determined the levelized costs of energy savings. Results showed that financial support for energy efficiency improvements in industrial enterprises has been most effective, mainly due to the low co-financing rate $(30 \%)$ and the high potential for energy savings in different production processes. Authors have identified the blind-spots within the funding allocation for different municipalities which is not always dedicated to achieved energy savings. The achieved energy savings and costs in case of analysed DH network reconstruction projects is highly influenced by the diameters of changed pipes. Several projects included the construction of new heating lines which does not result in direct saving of energy, but brings the overall benefits in case of increased heat density.

Based on the analysis of the abovementioned energy efficiency and RES support programs, it can be seen that the implemented programs need to be more targeted in order to maximize energy savings through the allocated funding. The implementation of a monitoring system and public access to data related to achieved energy savings is essential to assess the effectiveness of the provided funding.

The obtained results can be used when the policy maker need to identify the most cost-effective support programs to achieve the energy efficiency and climate targets. Further analyses could include the main factors, which can affect the obtained energy saving of different supported projects as well as further comparison of other policy instruments, for example, feed-in tariffs.

Author Contributions: Conceptualization, I.P.; Data curation, I.P.; Formal analysis, I.P.; Funding acquisition, D.L. and D.B.; Methodology, I.P. and D.L.; Project administration, D.L. and D.B.; Validation, I.P., D.L. and D.B.; Visualization, I.P.; Writing-original draft, I.P.; Writing—review and editing, I.P., D.L. and D.B. All authors have read and agreed to the published version of the manuscript.

Funding: This research is funded by the Latvian Council of Science, project "Blind spots in the energy transition policy (BlindSpots)", project No. lzp-2018/2-0022.

Conflicts of Interest: The authors declare no conflict of interest.

\section{References}

1. Rehman, H.; Hirvonen, J.; Jokisalo, J.; Kosonen, R.; Sirén, K. EU Emission Targets of 2050: Costs and $\mathrm{CO}_{2}$ Emissions Comparison of Three Different Solar and Heat Pump-Based Community-Level District Heating Systems in Nordic Conditions. Energies 2020, 13, 4167. [CrossRef]

2. Romanchenko, D.; Nyholm, E.; Odenberger, M.; Johnsson, F. Balancing investments in building energy conservation measures with investments in district heating-A Swedish case study. Energy Build. 2020, 226, 110353. [CrossRef] 
3. Criscuolo, C.; Menonac, C. Environmental policies and risk finance in the green sector: Cross-country evidence. Energy Policy 2015, 83, 38-56. [CrossRef]

4. Bian, J.; Zhao, X. Tax or subsidy? An analysis of environmental policies in supply chains with retail competition. Eur. J. Oper. Res. 2020, 283, 901-914. [CrossRef]

5. Locmelis, K.; Bariss, U.; Blumberga, D. Energy Efficiency Obligations and Subsidies to Energy Intensive Industries in Latvia. Environ. Clim. Technol. 2019, 23, 90-101. [CrossRef]

6. Dusonchet, L.; Telaretti, E. Economic analysis of different supporting policies for the production of electrical energy by solar photovoltaics in eastern European Union countries. Energy Policy 2010, 38, 4011-4020. [CrossRef]

7. Iov, F.; Khatibi, M.; Bendtsen, J.D. On the Participation of Power-To-Heat Assets in Frequency Regulation Markets-A Danish Case Study. Energies 2020, 13, 4608. [CrossRef]

8. Andor, M.A.; Voss, A. Optimal renewable-energy promotion: Capacity subsidies vs. generation subsidies. Resour. Energy Econ. 2016, 45, 144-158. [CrossRef]

9. Ozdemir, O.; Hobbs, B.F.; Hout, M.; Koutstaal, P.R. Capacity vs energy subsidies for promoting renewable investment: Benefits and costs for the EU power market. Energy Policy 2020, 137, 111166. [CrossRef]

10. Abrell, J.; Kosch, M.; Rausch, S. Carbon abatement with renewables: Evaluating wind and solar subsidies in Germany and Spain. J. Public Econ. 2019, 169, 172-202. [CrossRef]

11. Marcantonini, C.; Valero, V. Renewable energy and CO 2 abatement in Italy. Energy Policy 2017, 106, 600-613. [CrossRef]

12. Kuusk, K.; Kalamees, T. Estonian Grant Scheme for Renovating Apartment Buildings. Energy Procedia 2016, 96, 628-637. [CrossRef]

13. Toleikyte, A.; Kranzl, L.; Müller, A. Cost curves of energy efficiency investments in buildings-Methodologies and a case study of Lithuania. Energy Policy 2018, 115, 148-157. [CrossRef]

14. Blumberga, A.; Cilinskis, E.; Gravelsins, A.; Svarckopfa, A.; Blumberga, D. Analysis of regulatory instruments promoting building energy efficiency. Energy Procedia 2018, 147, 258-267. [CrossRef]

15. Ziemele, J.; Pakere, I.; Blumberga, D. The future competitiveness of the non-Emissions Trading Scheme district heating systems in the Baltic States. Appl. Energy 2016, 162, 1579-1585. [CrossRef]

16. Arabzadeh, V.; Lund, P.D. Effect of Heat Demand on Integration of Urban Large-Scale Renewable Schemes-Case of Helsinki City $\left(60^{\circ} \mathrm{N}\right)$. Energies 2020, 13, 2164. [CrossRef]

17. Aboltins, R.; Blumberga, D. Key Factors for Successful Implementation of Energy Efficiency Policy Instruments: A Theoretical Study and the Case of Latvia. Environ. Clim. Technol. 2019, 23, 187-206. [CrossRef]

18. Safarzadeh, S.; Rasti-Barzoki, M.; Hejazi, S.R. A review of optimal energy policy instruments on industrial energy efficiency programs, rebound effects, and government policies. Energy Policy 2020, 139, 111342. [CrossRef]

19. Cho, H.I.; Freyre, A.; Bürer, M.; Patel, M.K. Comparative analysis of customer-funded energy efficiency programs in the United States and Switzerland-Cost-effectiveness and discussion of operational practices. Energy Policy 2019, 135, 111010. [CrossRef]

20. Sneum, D.M.; Sandberg, E.; Koduvere, H.; Olsen, O.; Blumberga, D. Policy incentives for flexible district heating in the Baltic countries. Util. Policy 2018, 51, 61-72. [CrossRef]

21. CCFI Information. Available online: http://kpfi.lv/index.php?page=konkursi_lv (accessed on 27 August 2020).

22. EU Funds. Available online: https://m.esfondi.lv/upload/14-20_gads/FMProg_070114_DP_VSS.pdf (accessed on 27 August 2020).

(C) 2020 by the authors. Licensee MDPI, Basel, Switzerland. This article is an open access article distributed under the terms and conditions of the Creative Commons Attribution (CC BY) license (http://creativecommons.org/licenses/by/4.0/). 